\title{
O APOIO À CONSTRUÇÃO DA POLÍTICA NACIONAL DE DESENVOLVIMENTO URBANO'
}

\author{
Marco Aurélio Costa ${ }^{2}$ \\ Lizandro Lui ${ }^{3}$
}

Em dezembro de 2019, a Secretaria Nacional de Desenvolvimento Regional e Urbano (SDRU), do Ministério do Desenvolvimento Regional (MDR), e o Ipea assinaram um termo de execução descentralizada (TED), visando ao estabelecimento de uma parceria institucional voltada para apoiar o processo de construção da Política Nacional de Desenvolvimento Urbano (PNDU).

O MDR tem, desde 2019, o mandato de algumas das principais politicas espaciais, na esfera do governo federal, acolhendo atribuiçóes que antes se encontravam compartilhadas entre os antigos ministérios das Cidades e da Integração, de modo que está sob sua responsabilidade a execução da Política Nacional de Ordenamento Territorial (PNOT), da Política Nacional de Irrigação, da Política Nacional de Desenvolvimento Regional (PNDR) e da formulação da própria PNDU.

O Ipea vem desenvolvendo, há alguns anos, por meio de diferentes iniciativas, um robusto trabalho de colaboração técnica voltado para a implementação e o acompanhamento da PNDR. Em um aprofundamento das relaçóes de parceria institucional que envolvem o MDR e o Ipea, mais precisamente a Dirur, compreendendo a importância de buscar uma articulaçáo entre PNOT, PNDR e PNDU, o MDR propôs o estabelecimento de uma nova parceria, envolvendo, desta vez, a Coordenaçáo de Estudos em Desenvolvimento Urbano (Codur), visando ao apoio à construção da PNDU.

$\mathrm{Na}$ justificativa para o TED que viria a ser firmado em dezembro, ${ }^{4}$ o MDR sublinha que as políticas territoriais são complementares, ainda que partam de escopos e escalas diferentes, sendo fundamental sua articulação.

1. DOI: http://dx.doi.org/10.38116/brua24art19

2. Técnico de planejamento e pesquisa e coordenador de Estudos em Desenvolvimento Urbano na Diretoria de Estudos e Políticas Regionais, Urbanas e Ambientais (Dirur) do Ipea; coordenador nacional do Instituto Nacional em Ciência e Tecnologia em Política Pública e Desenvolvimento Territorial (INPuT); e doutor em planejamento urbano e regional. E-mail:<marco.costa@ipea.gov.br>.

3. Pesquisador do Programa de Pesquisa para o Desenvolvimento Nacional (PNPD) na coordenação de Estudos em Desenvolvimento Urbano da Dirur/lpea. E-mail: <lizandro.lui@ipea.gov.br>.

4. TED oㅜ 71/2019, assinado pela então secretária nacional de desenvolvimento regional e urbano, em 9 de dezembro de 2019, e pelo presidente do Ipea, em 13 de dezembro. 
Ao contrário da PNDR, que já conta com uma versão atualizada, instituída por meio do Decreto no 9.810 , de 30 de maio de 2019, o desenvolvimento urbano ainda náo conta com uma política formalmente estruturada na esfera federal.

É bem verdade que, do ponto de vista jurídico-normativo, o Estatuto da Cidade (EC), Lei Federal no 10.257, de junho de 2001, estabeleceu as diretrizes gerais da política urbana no país. O EC tem sido observado, sobretudo pelos governos municipais, no tocante às atribuiçóes que foram conferidas a seus gestores. Contudo, do ponto de vista da estruturaçáo de uma política nacional, há ainda um percurso a ser vencido, no qual seja mais bem explicitado o papel da Uniáo para o desenvolvimento urbano, em suas relaçóes com os demais níveis da Federação, com vistas à construção de um marco de cooperação que contribua para a efetividade das diretrizes gerais da política urbana.

O desafio em tela trata-se, pois, da construção da PNDU, para a qual o Ipea colaborará por meio da produçáo de um conjunto de notas técnicas e documentos executivos, além de eventos de articulação técnica e institucional.

No TED original, de dezembro de 2019, duas são as principais etapas que envolvem maior engajamento por parte do Ipea: a produção de elementos que permitam pensar na agenda urbana, em suas diferentes e complementares escalas, no que se denominou de novo pacto urbano brasileiro; e a organização de uma reflexáo sobre o desafiador tema do financiamento do desenvolvimento urbano.

No que diz respeito à agenda urbana, já foi apresentada ao MDR uma primeira nota técnica conceitual abordando a contextualização do atual processo de construção da PNDU. Essa primeira nota técnica, exposta e discutida com a equipe da Coordenação-Geral de Apoio à Gestão Regional e Urbana (CGAGRU), está em processo final de revisão e será disponibilizada brevemente.

A nota apresenta o percurso da política urbana no país, tendo como referência os marcos legais relativos à política, em especial após a Constituição Federal de 1988 (CF/1988), abordando a questáo territorial no contexto do federalismo brasileiro, explorando as iniciativas associadas à efetivaçáo do direito à cidade e trazendo, ainda, propostas de agendas transversais que informam, qualificam e contextualizam os (novos) desafios colocados para a política urbana no país.

A partir dessa nota, estáo sendo elaboradas mais quatro notas técnicas que debatem a agenda urbana brasileira, abarcando as escalas municipal, supramunicipal e regional e a questão das relaçôes interfederativas.

Quanto ao financiamento do desenvolvimento urbano, uma versão preliminar de uma primeira nota técnica, tratando da questão fiscal e extrafiscal, já foi entregue ao MDR. Outras notas abarcando as transferências intergovernamentais, o acesso a recursos onerosos e não onerosos e também a questão das parcerias entre os setores público e privado para o financiamento do desenvolvimento urbano estão sendo elaboradas, estando inseridas na versão original do TED.

Em maio de 2020, visando ampliar ainda mais a articulação entre Codur/Dirur/Ipea e CGAGRU/SNMAU 5 /MDR, o Aditivo ao TED no 71/2019 foi assinado, aumentando os

5. Secretaria Nacional de Mobilidade e Desenvolvimento Regional e Urbano. 
recursos transferidos para o Ipea e alargando o prazo para a realização das açôes acordadas entre as partes.

Com o aditivo, será possível ampliar o campo temático dos estudos que subsidiarão o processo de construção da PNDU. Isso inclui temas de agendas transversais (equidade social e viés intergeracional, segurança pública, meio ambiente, transformação digital e desenvolvimento econômico) e outros ligados à participação de segmentos sociais no processo de elaboração da PNDU, com vistas à construção de uma governança multinível.

Com efeito, as notas técnicas que estáo sendo desenvolvidas pela equipe da Codur têm como objetivo aprofundar o debate sobre a questão urbana no Brasil. Seja tratando dos temas diretamente associados à nova agenda urbana, dos temas transversais, da questáo do financiamento ou das discussóes em torno do federalismo brasileiro, espera-se que a contribuição técnica da equipe envolvida possa subsidiar o MDR e permitir que, nos próximos meses, esteja formulada uma primeira proposta de uma PNDU capaz de contribuir para o enfrentamento de velhas e novas questóes que desafiam as cidades brasileiras e demandam a atenção e a atuação do poder público, inclusive da Uniáo.

Por fim, ressalta-se o importante papel desempenhado pelo Ipea enquanto órgão que busca qualificar o debate em torno da formulação das políticas públicas - em especial das políticas de desenvolvimento urbano. Ao longo dos últimos anos, contribuímos para a construção do conhecimento relativo ao desenvolvimento urbano no país, tanto pela construção da plataforma Governança Metropolitana, desenvolvida no âmbito da Codur, quanto pela produção de livros, artigos, notas técnicas etc. Sendo assim, novamente, a instituição reforça a sua importância para a construção das políticas e para o desenvolvimento do país. 
